\title{
IL11 Gene
}

National Cancer Institute

\section{Source}

National Cancer Institute. IL11 Gene. NCI Thesaurus. Code C28601.

This gene plays a role in the regulation of cell proliferation and differentiation. 